\title{
Refractory Hypertension in Childhood
}

\author{
- Efficacy of Captopril Therapy -
}

\author{
Minoru Yamagishi, Mitsunobu KaneKo, Kohichi Chiba, \\ Taro OHJI and Takeo KOHRI \\ Department of Pediatrics, School of Medicine, University of Occupational and \\ Environmental Health, Japan. Kitakyushu 807, Japan
}

Abstract: Because of the advance of techniques and age-matched apparatus for blood pressure measurement, and because of the availability of age-related normal values in childhood, the knowledge of the number of children having elevated blood pressures has recently improved. In a group of healthy children, the first important task is to determine how many incidences of "essential hypertension" there are among them, which may appear in childhood and persist into adulthood. This should urge us to undertake periodical examinations of healthy children. On the other hand, the treatment of "secondary hypertension" has similarly been improved. Since 1979 in particular, captopril, an orally active angiotensin I-converting enzyme inhibitor, has successfully been administered to treat children with malignant hypertension and who respond poorly to conventional antihypertensive therapies. We report 3 cases that received captopril for refractory hypertension: a 2-year-old boy with renal and renovascular anomalies, a 7 year-old boy with moyamoya disease after surgical operation, and a 17-year-old youth with Cushingoid syndrome due to chronic administration of steroids against mixed connective tissue disease. After the introduction of captopril, good pressure control was obtained in all 3 cases, although reasonable effects of measurement values of the renin-angiotensin-aldosterone system (decrease in angiotensin I \& II, increase in I/II ratio, etc.) were found only in the first case.

Key words: childhood hypertension, renovascular hypertension, moyamoya disease, Cushingoid syndrome, captopril (angiotensin I-converting enzyme inhibitor).

(Received 10 August 1987)

\section{Introduction}

Because increasing numbers of children are being identified as having elevated blood pressure since the recent availability of age-matched measurements and of age-related normal values in children (Prebis et al., 1981), and because it may be presumed as a onset of seijin-byoh (adult diseases) contributing to the high incidence of coronary artery disease, cerebrovascular accidents, congestive heart failure, and renal compromise (Rosen et al., 1985), pediatric hypertension has received increased recognition. However, these hypertensions must be divided into two types, i.e. essential and secondary hypertension.

Concerning the former type, it is not yet completely clear how much evidence of essential hypertension there is among children with elevated blood pressure, and how many potential patients with essential hypertension there are among children or adolescents. In our recent data, in 12 to 13-year-old healthy children, 13 of 142 boys and 13 of 150 girls 
documented the systolic pressure $\geqq 125 \mathrm{mmHg}$ (Ohji et al., 1987), roughly agreeing with the frequency in population studies by other authors. Perhaps, essential hypertension among these children is not easy to define, nor so frequent. We shall present more detailed results in the near future.

On the other hand, the latter type, that is secondary hypertension, has been found in the majority of hypertensive children. According to Leumann (1983), among them 3 of 4 pediatric patients were described as having secondary hypertension due to renal parenchymal diseases (glomerulonephritis for 39\%, pyelonephritis for $20 \%$ and other renal diseases for $19 \%$ ), and in the remaining patient it was due to miscellaneous diseases (diseases of heart and circulation for 12\%, renovascular diseases for $5 \%$ and other diseases for $5 \%$ ). According to Rauh (1983), endocrine and neurological diseases were rare causes of arterial hypertension in childhood, and represented less than $5 \%$ of all cases of secondary hypertension. Newer forms of hypertension may be observed after catheterization of the umbilical artery in newborns, and after renal transplantation (Leumann, 1983).

Also the treatment of hypertension in children, as stated by Brandis (1983) and most authors, has been established: starting from non-pharmacological procedures such as low salt diet, bodyweight control and exercise; adding antihypertensive drugs such as diuretics, $\beta$-blocker, vasodilator etc.; and combining radical therapies for basic diseases including surgical operations. Moreover, a new orally active angiotensin I-converting enzyme inhibitor, captopril, has been used in severe, uncontrollable cases for the last eight years, demonstrating that this drug is a most effective one for a wide variety of pediatric patients (Mirkin \& Newman, 1985). We report here our successful experience with this drug in 3 refractory hypertensive children, although a complete cure is still difficult.

\section{Case Reports}

Case 1.

A 2-year and 1-month-old boy was the second of twins born at 37 weeks of gestation to healthy and unrelated parents, weighing $2032 \mathrm{~g}$. At the age of 1 year and 2 months, when the blood pressure is not measured, he had intussusception. No other disorders were noticed during those months except occasional excessive drinking and urinating. The other male twin weighed $2386 \mathrm{~g}$ at birth, had no feeding problem, and developed without anomalies.

At the age of 1 year and 11 months he suffered from rubella, and was diagnosed as having a heart murmur. About a month later, he began to sweat excessively, his face became pale, he suffered from short, rapid breathing and dyspnea on exertion, such as gasping for breath after a few-minutes walk, but without signs such as unconsciousness, cramps, vomiting, headaches, and precordial pain and oppression. At 2 years and 1 month he was sent to our ward for confirmation of the diagnosis.

On physical examination on admission (Jan., 31 th), he was $86.2 \mathrm{~cm}$ tall, weighed 10.2 
$\mathrm{kg}$, and had normal face color without cyanosis. His pulse and respiration rates were rapid, 180/min and 60/min, respectively. His heart sound involved S1: n1, S2: splitting, II $\mathrm{a}=$ II $\mathrm{p}$, and Gr. 2 high pitched ejection murmur at ULSB, while clear sounds were heard over the lung field. The abdomen was flat and soft, and the liver edge was palpable 1.5 $\mathrm{cm}$ below the costal margin. There was no indication of splenomegaly. The left kidney was also palpable $4 \mathrm{~cm}$ below the left costal margin. High blood pressure was discovered to be RA: 220/150, LA: 216/148, RL: 224/150, and LL: 226/152 mmHg.

Laboratory findings including those of hematology and acute phase reactants were: $\mathrm{RBC}, 596 \times 10^{4} / \mathrm{mm}^{3} ; \mathrm{Hb}, 14.2 \mathrm{~g} / \mathrm{dl} ; \mathrm{WBC}, 13200 / \mathrm{mm}^{3} ; \mathrm{ESR}, 15 \mathrm{~mm} / \mathrm{h}$; and CRP (-); of blood chemistry were: total protein, $6.4 \mathrm{~g} / \mathrm{dl}$; albumin, $3.9 \mathrm{~g} / \mathrm{dl} ; \mathrm{Na}, 140 \mathrm{mEq} / \ell ; \mathrm{K}, 4.4$ $\mathrm{mEq} / \ell$; Gl, $105 \mathrm{mEq} / \ell$; Ca, $9.7 \mathrm{mg} / \mathrm{dl} ; \mathrm{GOT}, 35 \mathrm{U} / \ell$; GPT, $16 \mathrm{U} / \ell$; BUN, $30 \mathrm{mg} / \mathrm{dl}$; creatinine, $0.3 \mathrm{mg} / \mathrm{dl}$; plasma renin activity, $380.0 \mathrm{ng} / \mathrm{ml} / \mathrm{hr}$; angiotensin I , $38000 \mathrm{pg} / \mathrm{ml}$; angiotensin II , $1200 \mathrm{pg} / \mathrm{ml}$; aldosterone, $2048.0 \mathrm{pg} / \mathrm{ml}$; and $\beta_{2}$-microglobulin, $3.30 \mathrm{mg} / \mathrm{dl}$; and of urinalysis and others were: urinary protein $(+)$; urinary occult blood $(+)$; creati-

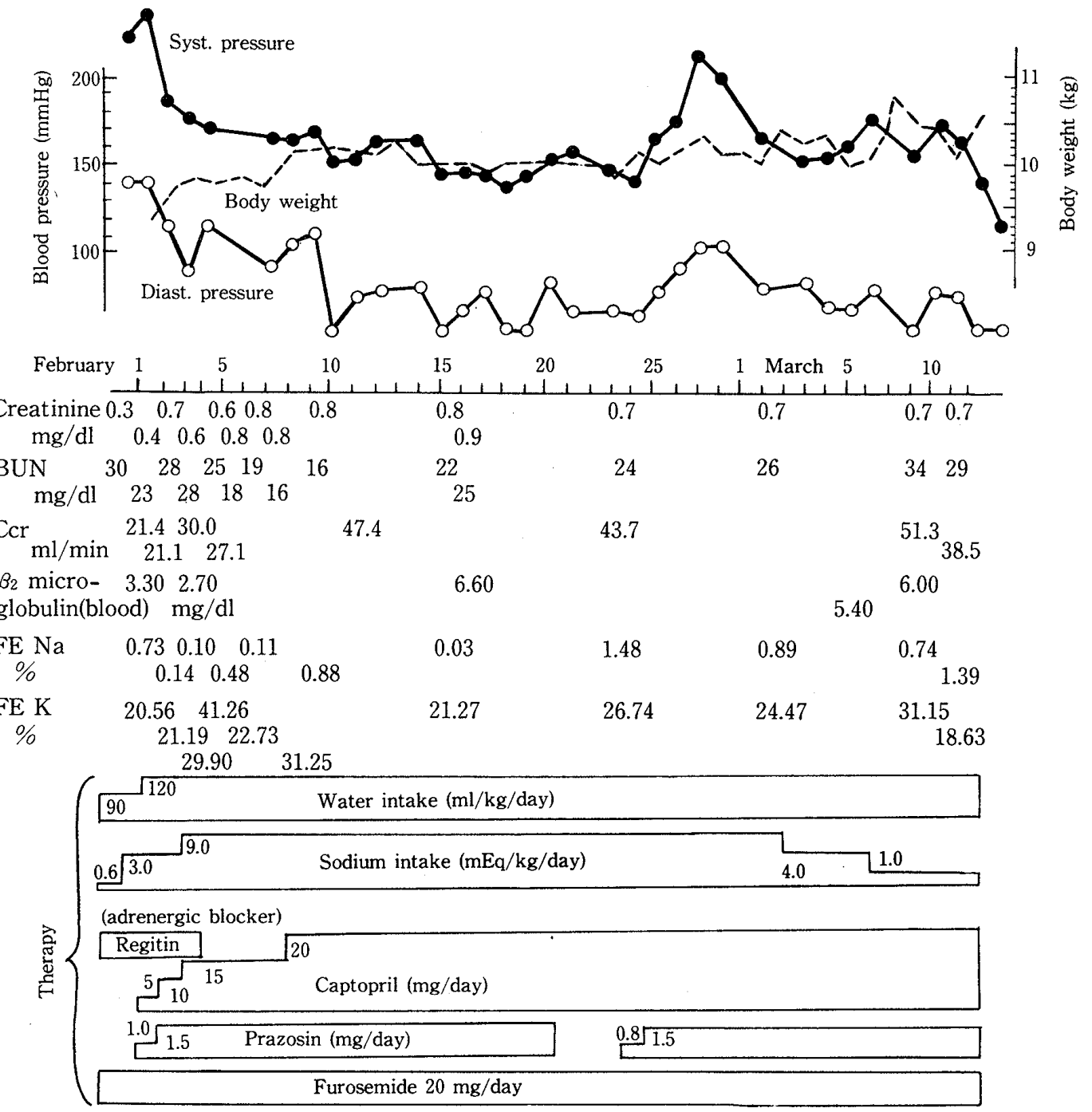

Fig. 1. Case 1 (2yrs, male): Renovascular hypertension and one-side kidney. 
nine clearance $21.4 \mathrm{ml} / \mathrm{min}$; and fractional excretion of $\mathrm{Na}, 0.73 \%$ (partly seen in Fig. 1 and Table 1).

The chest X-ray showed a cardiomegaly with pulmonary congestion, the ECG sinus tachycardia, $\operatorname{LAD}\left(-20^{\circ}\right)$ and deep $\mathrm{S}$ in VI and tall $\mathrm{R}$ in $\mathrm{V}_{5}=48-50 \mathrm{~mm}$, suggesting LVH, and the UCG remarkable LV dilatation, LVPW thickening, and low ejection fraction (0.39, $0.5-0.8$ in normal controls). The angiography of the left-side renal arteries revealed stenotic and dilated segments, bending, meandering and contracting as seen in Fig. 2. Moreover, absence of the right-side kidney was confirmed by abdominal echo, scintigraphy, IVP and CT scan.

Soon after admission, as seen in Fig. 1, restriction of water and sodium intake and administration of diuretics, $\beta$-blockers, vasodilators and captopril were started. This treatment resulted in good pressure control as well as significant decreases in plasma renin

Table 1. Measurement values of plasma renin activity, angiotensin I \& II, and aldosterone concentration

\begin{tabular}{|c|c|c|c|c|c|c|c|c|}
\hline \multirow{2}{*}{$\begin{array}{l}\text { Case } \\
\text { Date }\end{array}$} & \multicolumn{2}{|c|}{ Case 1} & \multicolumn{3}{|c|}{ Case 2} & \multicolumn{2}{|c|}{ Case 3} & \multirow[b]{2}{*}{ Adult controls } \\
\hline & Feb. 2. & Feb. 23. & May 22. & May 24. & Jun. 3. & Feb. 27 & Mar. 1. & \\
\hline Plasma renin activity & 380.0 & 74.0 & 15.0 & 13.0 & 18.0 & 1.4 & 7.1 & $0.5-2.0 \mathrm{ng} / \mathrm{ml} / \mathrm{hr}$ \\
\hline Angiotensin I & 38000 & 3500 & 1600 & 930 & 1300 & 54.0 & 150.0 & $<200 \mathrm{pg} / \mathrm{ml}$ \\
\hline Angiotensin II & 1200 & 34 & 26 & 30 & 49 & 9.0 & 13.0 & $<100 \mathrm{pg} / \mathrm{ml}$ \\
\hline A I / A II ratio & 31.7 & 102.9 & 61.5 & 31.0 & 26.5 & 6.0 & 11.5 & \\
\hline Aldosterone & 2048.0 & 99.6 & 201.20 & 184.10 & 459.20 & $<10.0$ & 51.7 & $52.10-175.10 \mathrm{pg} / \mathrm{ml}$ \\
\hline
\end{tabular}

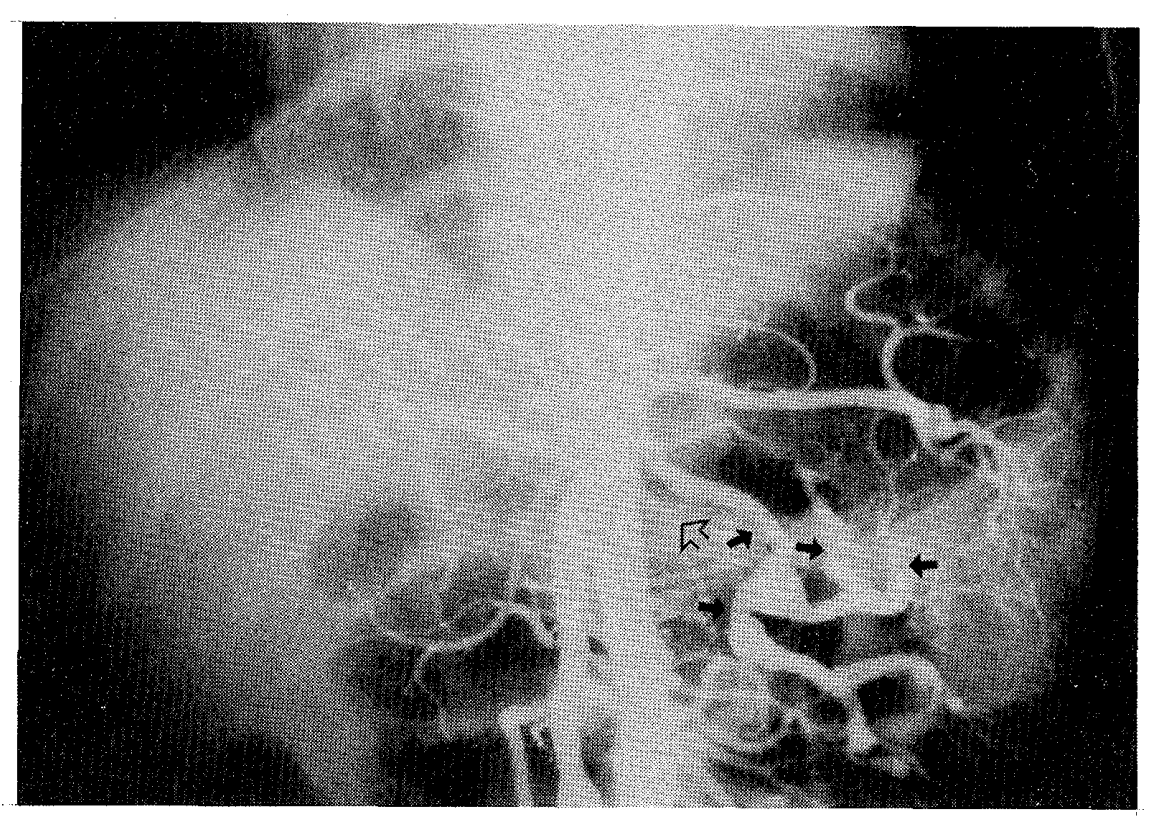

Fig. 2. The aortogram (Case 1) shows markedly irregular arterial wall in lower abdominal aorta, no blood supply to right kidney, occulusion of left main renal artery ( $仓$ ), and multiple stenosis in collateral artery to left kidney and in left segmental arteries ( $)$. 
activity, angiotensin I \& II, and aldosterone concentration, increasing angiotensin I/ II ratio, as seen in Table 1. We discussed, of course, whether a surgical operation should be indicated, but decided on the conservative treatment for the time being because of (1) persistence of vasculitis suggested by angiographic findings as severe, multiple anomalies, (2) possibility of the appearance of arterial re-stenosis after surgical operation, and (3) possibility of the induction of intravascular angioplasty with balloon in the not too distant future.

Case 2.

The patient was a 7-year-old boy who was born by cesarean section at 38 weeks of gestation, weighing $2840 \mathrm{~g}$, to healthy and unrelated parents. His sibling, younger sister, was also healthy, but a mother's elder sister had multiple sclerosis.

At the age of 2 years, he had an episode of crying violently for ten minutes and transient weakening of his left arm and leg. At the age of 3 years and 6 months, he revealed left-sided hemiparesis, was diagnosed as having moyamoya disease, and received the superficial temporal-middle cerebral artery anastomosis (STG-MCA) in a brain-surgery clinic.

After the surgical operation, right-sided hemiparesis and aphasia appeared and persisted, and at the age of 6 years he entered a rehabilitation-center, where his blood pressure was found to be 140/70. At 7 years, he was sent to our ward because of not only elevated blood pressures of $170-200 / 90-120$ but also high levels of plasma renin activity: $13.8 \mathrm{ng} /$ $\mathrm{ml} / \mathrm{h}$ and aldosterone concentration: $20 \mathrm{ng} / \mathrm{dl}$.

On admission (May, 16th), a low salt diet and vasodilator were added to anticonvulsants, minor tranquilizers, laxatives, expectorants and cephem antibiotics as shown in Fig. 3. Some degree of decrease in blood pressure was obtained due to the wide range of

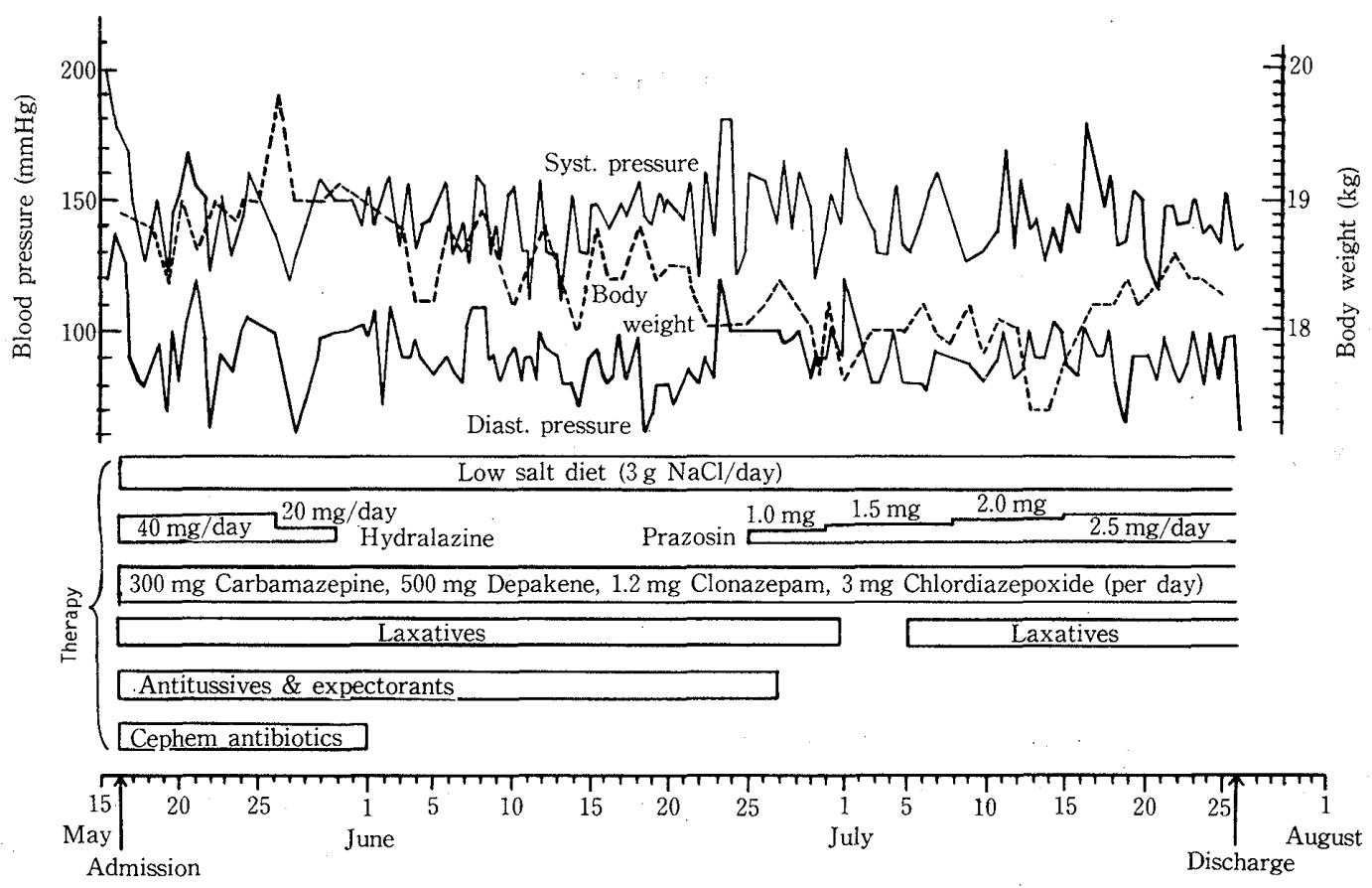

Fig. 3. Case 2 (7yrs, male): Moya-moya disease (post operative) and hypertension. 
change, for example, 120-180/60-120. As seen in Table 1, during the course, no significant changes in values of the renin-angiotensin-aldosterone system were noticed. Although the renal angiography showed no abnormal arteries, we could not completely deny the existence of arterial lesions in organs other than the intracranial ones because of his moyamoya disease.

After discharge (Jul., 26th) his blood pressure was still $144-158 / 80-100$ with occasional episodes of increase. Because of this condition, captopril $(12.5 \mathrm{mg} / \mathrm{day})$ was added 2 months later. Since then, lower pressures, $110-150 / 60-80$, are persisting.

Case 3.

This 17-year-old male youth developed a collagen disease at the age of 13 years, before then he had been quite healthy. There was no family history of similarly affected members: his father had already died in an accident, his mother is healthy, and there are no siblings.

He has been admitted to our ward a total of 6 times, 4 times for treatment with steroids for his suspected dermatomyositis. On the 5 th admission at the age of 15 years, a diagnosis of mixed connective tissue disease (MCTD) was first made. Since then the treatment including steroid administration for this disease as well as for complications like congestive heart failure and obesity were performed (Yamagishi et al., 1983). Moreover, on the 6th admission at 17 years, high blood pressures such as 220-230/150-160 were being controlled with antihypertensive agents. Based on the severity of his disease, administration of captopril was tried regardless of the values of the renin-angiotensin-aldosterone system as shown in Table 1. Good pressure control was obtained as seen in Fig. 4.

\section{Discussion}

As a radical therapy for secondary hypertension, a surgical operation may be indicated for artery isthmus stenosis, endocrine active tumors like pheochromocytoma, and most forms of renovascular lesions (Schärer, 1987). A variety of methods have been employed to correct renal artery stenosis and the resulting hypertension, including transluminal dilation of the stenotic segment of the renal artery, bypass grafting around the stenotic area, total or partial nephrectomy, and embolization of the stenotic area (Warren et al., 1982). Also in our Case 1, an induction of surgical reconstruction to his renovascular lesions was considered, but a conservative procedure was decided on because of above mentioned reasons (1), (2) and (3). For the present, we must control his hypertension which is contributing to the high incidence of renal failure as seen on admission in Fig. 1, of heart failure especially in his left heart as seen before and on admission, and finally of arteriosclerosis.

Captopril, representing a new mode of high-potent antihypertensive drug used in the case of adults since 1978, was introduced first by Oberfield et al. (1979) to treat a child with malignant hypertension. The efficacy and safety of captopril in the treatment of severe 


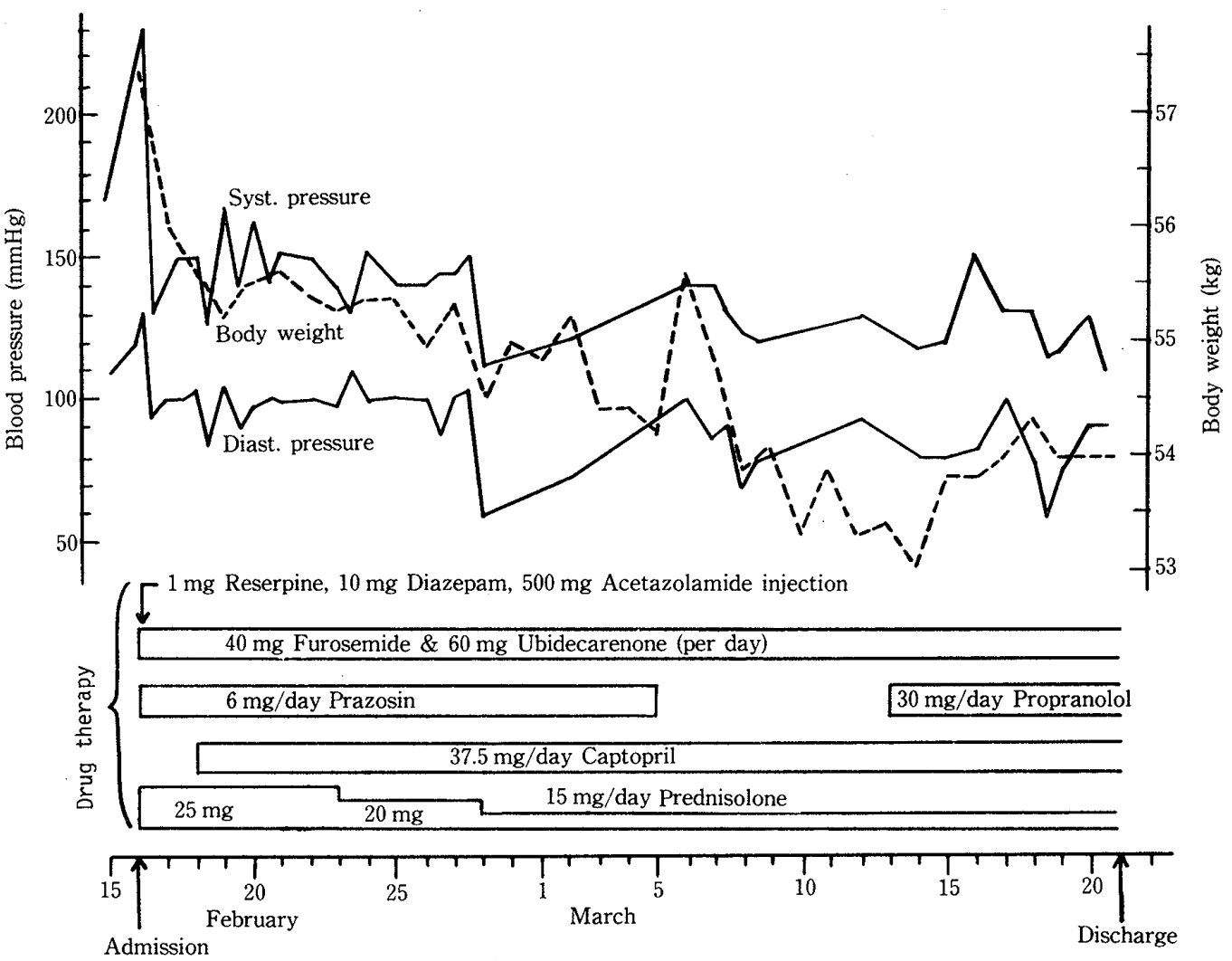

Fig. 4. Case 3 (17yrs, male): Mixed connective tissue disease and Cushingoid syndrome due to chronic administration of steroids.

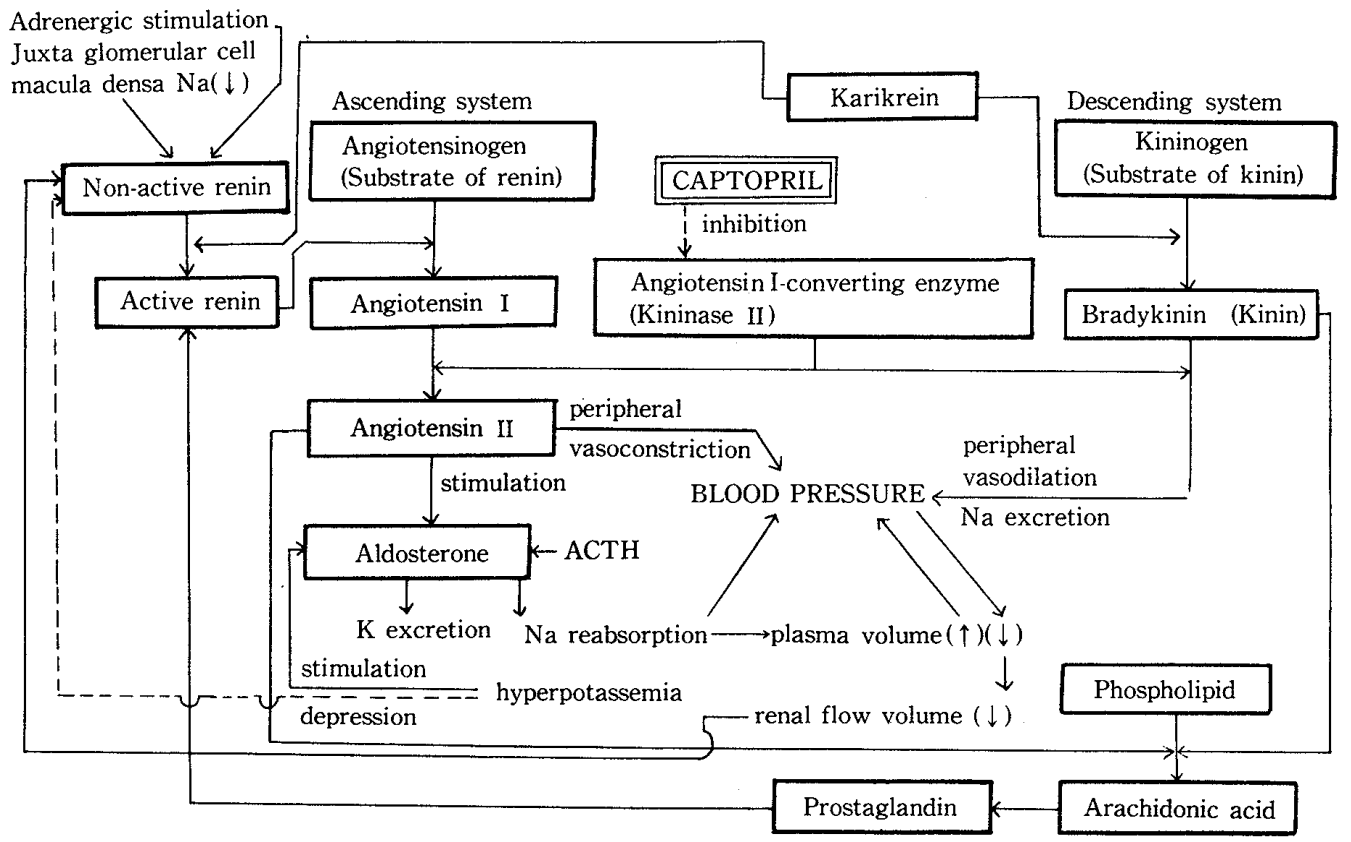

Fig. 5. Schema of renin-angiotensin-aldosterone system, blood pressure, and captopril (angiotensin I-converting enzyme inhibitor). 
hypertensive children having been reported by an increasing numbers of pediatricians, and the largest number of patients was treated by the international collaborative study group (Mirkin \& Newman, 1985). This drug, as shown in Fig. 5, does not permit the conversion of angiotensin I to angiotensin II, which causes the resultant decrease in angiotensin II production in the activity of its potent vasoconstrictor, and in aldosterone secretion by the adrenal glands. By lowering the aldosterone concentration, as stated by Friedman et al. (1980), this drug obviates the sodium retention often resulting from antihypertensive treatment. Lastly, the angiotensin I-converting enzyme is the same enzyme which catalyzes the breakdown of bradykinin, a kind of vasodilator. Thus, by inhibiting the enzyme, blood concentrations of bradykinin may rise and serve to lower blood pressure and promote natriuresis. Moreover, the ratio of angiotensin I to angiotensin II may reflect an indirect measure of converting enzyme activity, e.g. a high ratio would indicate the decreased conversion.

Based on these principles, the effect of captopril on the renin-angiotensin-aldosterone system was assessed in our 3 cases as shown in Table 1. Only Case 1 showed reasonable changes such as the decrease in plasma renin activity, angiotensin I \& II, and aldosterone concentration, and the increase in angiotensin I / II ratio. Good pressure control was obtained not only in Case 1 but also in Case 2 and 3. On the other hand, side-effects of captopril such as hematological disorders (Verhaaren et al., 1986), sudden fall in pressure (Bacri et al., 1980), hyperpotassemia (Lütkenhaus et al., 1980), renal failure with azotemia (Hricik et al., 1983) etc. have been reported, most of which seemed to be dose-related and reversible. In our 3 cases, none of these side-effects have yet developed. Moreover in Case 1, no significant influence upon renal tubulus was suggested by the results of Na- and K- fractional excretion as seen in Fig. 1 (Iwasaki \& Nakamura, 1987).

In Case 2 with moyamoya disease, no renovascular anomalies could be demonstrated with renal aortogram. In the literature, it is seen that severe hypertension in childhood is caused rarely by intracranial lesions such as a tumor, encephalitis, trauma, hypoxia and brain edema of other etiologies, and also by other nervous diseases like poliomyelitis, polyradiculitis (Guillain-Barré), polyneuropathy due to metabolic error or toxicosis, and dysautonomia (Riley-Day syndrome) (Rauh, 1983). Similarly, the coexistence of renovascular hypertension in central nervous diseases have been reported as in neurofibromatosis (Grad \& Rance, 1972; Tilford \& Kelsch, 1973), Rett's syndrome (Uhari \& Rantala, 1987), occlusion of circle of Willis (Ogawa et al., 1974), and moyamoya disease (Ellison et al., 1981). Also in Case 2, the arterial lesion in other organs is a possibility.

Finally, hypertensinogenic endocrine diseases in childhood have included catecholamine producing tumors such as pheochromocytoma and neuroblastoma, disorders of the adrenal cortex such as Cushing's syndrome, hyperaldosteronism, 11- \& 17- hydroxylase deficiency and apparent mineralocorticoid excess, renin producing tumors, hyperthyroidism, and hyperparathyroidism (Rauh, 1983). Our Gase 3 manifests Gushingoid syndrome with refractory hypertension due to chronic administration of steroids for MCTD which is also a 
refractory disease suggesting the difficulty of a final recovery.

\section{References}

Bacri, J. L., Dechaux, M., Gagnadoux, M. T. et al. (1980): Short term response and long term management with captopril in severe hypertension of children. (Abstract) Pediatr. Res., 14: 1009.

Brandis, M. (1983): Therapie des kindlichen Hochdrucks. Mschr. Kinderheilk., 131: 833-836.

Ellison, P. H., Largent, J. A. \& Popp, A. J. (1981): Moya-moya disease associated with renal artery stenosis. Arch. Neurol., 38: 467.

Friedman, A., Chesney, R. W., Ball, D. et al. (1980): Effective use of captopril (angiotensin I-converting enzyme inhibitor) in severe childhood hypertension. J. Pediatr., 97: 664-667.

Grad, E. \& Rance, C. P. (1972): Bilateral renal artery stenosis in association with neurofibromatosis (Recklinghausen's disease): Report of two cases. J. Pediatr., 80: 804-808.

Hricik, D. E., Browning, P. J., Kopelman, R. et al. (1983): Captopril-induced functional renal insufficiency in patients with bilateral renal-artery stenoses or renal artey stenosis in a solitary kidney. N. Engl. J. Med., 308: 373-381.

Iwasaki, T. \& Nakamura, T. (1987): A nonsymptomatic hematuric schoolgirl with hypopotassemia. 17th Regional Meeting of West Japan of the Japan Nephrology Society. (in Japanese)

Leumann, E. P. (1983): Der renal-bedingte Hochdruck. Mschr. Kinderheilk., 131: 822-824.

Lütkenhaus, C., Bonzel, K., Diekmann, L. et al. (1980): Erfolgreiche Behandlung einer renalen Hypertension bei einem $2 \frac{1}{2}$ Jahre alten Mädchen mit dem Converting-Enzym-Inhibitor Captopril. Mschr. Kinderheilk., 128: 724-726.

Mirkin, B. L. \& Newman, T. J. (1985): Efficacy and safety of captopril in the treatment of severe childhood hypertension: Report of the international collaborative study group. Pediatrics, 75: 1091-1100.

Oberfield, S. E., Case, D. B., Levine, L. S. et al. (1979): Use of oral angiotensin I-converting enzyme inhibitor (captopril) in childhood malignant hypertension. J. Pediatr., 95: 641-644.

Ogawa, Y., Hosoda, Y. \& Matsuyama, H. (1974): An autopsy case of occlusion of the circle of Willis in a child. Brain and Nerve, 26: 483-487. (in Japanese)

Ohji, T., Chiba, K., Kawada, Y. et al. (1987): Epidemiology of hypertension in children. Part 1. - Mass screening of blood pressure in healthy children - IV Annual Meeting of the UOEH Association of Health Sciences, 1986. Proceeding: J. UOEH, 9: 97. (in Japanese)

Prebis, J. W., Gruskin, A. B., Polinsky, M. S. et al. (1981): Uric acid in childhood essential hypertension. Pediatrics, 98: 702-707.

Rauh, W. (1983): Der endokrine und der neurogene Hochdruck im Kindesalter. Mschr. Kinderheilk., 131: $825-829$.

Rosen, P. R., Treves. S. \& Ingelfinger, J. (1985): Hypertension in children. Increased efficacy of technetium Tc 99m succimer in screening for renal disease. Am. J. Dis. Child., 139: 173-177.

Schärer, K. (1987): Neue Aspekte der Hypertonie beim Kind und Jugendlichen. Mschr. Kinderheilk., 135: $66-75$.

Tilford, D. L. \& Kelsch, R. C. (1973): Renal artery stenosis in childhood neurofibromatosis. Am. J. Dis. Child., 126: 665-668.

Uhari, M. \& Rantala, H. (1987): Renovascular hypertension in a child with Rett's syndrome. Acta Paediatr. Scand., 76: $372-374$.

Verhaaren, H. A., Vande Walle, J. \& Devloo-Blanequaert (1986): Captopril in severe childhood hypertension- Reversible anaemia with high dosage. Eur. J. Pediatr., 144: 554-556.

Warren, W. C., Warshaw, B. L., Hymes, L. C. et al. (1982): Selective embolization of a stenotic intrarenal artery for control of hypertension. J. Pediatr., 101: 743-745.

Yamagishi, M., Nakamura, T., Sato, Y. et al. (1983): Mixed connective tissue disease (MCTD) and recent 
trend in child collagen disease. J. Pediatr. Practice, 46: 159-166. (in Japanese)

小児期難治性高血圧症

一カプトプリルの効果 —

山岸 稔・金子 光延・葉 宏一・大治 太郎・郡 建男 産業医科大学小児科学教室

要 旨: 近年, 小児の血圧測定技術の進歩と年令別正常値の確立に呼応して, 高血圧の小児数が増 えてきた。これは，健康児集団ならばこのうちに真の本態性高血圧症がどのくらい含まれ ているかを明らかにするのが緊急課題であることを示唆しており，われわれもこの調査を 進めている。一方，症候性高血圧症に対する診断技術も進歩し，小児期での実態も明らか になりつつある。さらにその治療法も順次確立され，ことに難治性のものもアンジオテン シン変換酵素阻害剂（カプトプリル）によってコントロールが可能となった。この実例と して 2 歳男児の腎血管性高血圧・片腎例， 7 歳男児のモヤモヤ病手術後例，17歳男子の 混合結合組織病・クッシング様症候群例を紹介するが，ただしレニン昇圧系への有意の効 果（血中アンジオテンシン I ・ II 抢よびアルドステロン各值低下，I／II 比上昇）は第 1 例のみで認めた。なお， 3 例とも最終的治癒を得ることは依然として困難である。

J. UOEH (産業医大誌), 9 ( 4): 401-410 (1987) 